Health Psychology Review (2014), Vol. 8, pp. 215-237.

Social history of health psychology: context and textbooks

Michael Murray*

School of Psychology, Keele University, Newcastle-under-Lyme, ST5 5BG, UK

(Received 15 September 2011; final version received 5 June 2012)

\begin{abstract}
Health psychology as a field of research and practice formally developed 30 years ago but it was prefigured by sustained debate within social and applied psychology about the nature of psychology and its role in society. This article considers this pre-history of health psychology and how the field has subsequently developed. It considers how its character is shaped by dominant ideas within psychology and is also enmeshed in broader social relations. To illustrate the changing character of health psychology it considers how the field is represented in a selection of popular textbooks. It concludes by considering the growth of some critical approaches within health psychology.
\end{abstract}

Keywords: History; Textbooks; Health psychology; Critical psychology 


\section{Social history of health psychology: Context and textbooks}

'[W]e do have strength, things can be different, and here are stories from the past that show it' (Loach, 2011)

As a relatively new field of research and practice within psychology, health psychology has tended not to attract much interest in its historical development. Indeed, its relative recency constrains our ability to view its development within a broad historical perspective which requires a certain temporal distance. The limited work that exists on the history of health psychology is more of the Whiggish variety (Harris, 2009) with a tendency to document internal successes in terms of individual achievements and organisational developments but with lesser reference to contextual factors (e.g. Wallston, 1997; Johnston, Weinman \& Chater, 2011). My aim in this article is to adopt a more critical approach with particular reference to the connection between health psychology and the changing socio-historical context and how it has been represented in popular textbooks.

It is argued that through a critical engagement with the history of the field it is possible to better understand its current shape and focus. Historical study should not be seen as a distraction from immediate concerns but as a process of excavation that can uncover hidden assumptions. In developing an account of the development of interest in health psychology we have the opportunity to critique the past but also to challenge current orthodoxies and begin to develop new approaches. Thus an understanding of our history provides an opportunity for reassessing the dominant orientation. Some historians of psychology have taken this advice seriously. In particular, Nikolas Rose in his research into the development of the 'psy' disciplines has argued that the study of history holds the potential of transforming current and future practice. As he stated, history can be used 'to resurrect a 
lost potential, to reactivate a forgotten destiny, to inscribe the possibility of an alternative future into the present by means of the past' (Rose, 1996; for further discussion on the forward looking potential of critical history see Teo, 2005). I use Rose's advice to frame my comments in this article such that my intention in looking back is to explore why it has followed one path and to consider alternative approaches within the field.

Rather than conducting an extensive review of empirical work this article focuses more on textbooks as providing an indicator of the dominant orientation within the field, the assumptions and values. There are an increasing number of health psychology textbooks but I have confined myself in this article to the key North American and British books which have been particularly influential in shaping the field. Although I reviewed over 20 such texts, in this paper I refer explicitly only to those that have gone through multiple editions indicating their popularity.

In reviewing these textbooks I have been especially interested in how the authors deliberately position themselves. This is often made explicit in the book preface and/or in the introductory chapter in which the authors provide some rationale for writing the book and what has influenced their choice and organisation of subject matter. Rather than accepting that the shape of health psychology is fixed I am concerned with how it has been shaped. Here I follow Stringer's (1990) advice that “Texts are persuasive; and a writer's principal aim, and difficulty, is to produce a simple, coherent account which will persuade the reader of its acceptability - that that is indeed how matters stand" (p. 18). 
There is an acceptance on the part of the author that the book can take various forms and that decisions have had to be made for the style and structure adopted. It is by critiquing these decisions that we can see how health psychology has been shaped over the past 30 years. But before that I consider briefly the social and intellectual context within which health psychology has developed.

\section{Beginnings}

While some textbooks of health psychology start with reference to ancient ideas about health and healthcare, in this paper I start with the immediate pre-history of the formal establishment of the field. In that sense I am following the tradition of distinguishing between the long past and the short history of psychology. Farr (1991) in his introduction to the history of social psychology recalled Ebbinghaus's earlier distinction between the 'long past' of psychology as part of philosophy and its 'short history' as part of mainstream science. While we can argue over the use of the term science it is sufficient here to define health psychology as that part of psychology which named itself as such in the 1970s.

However, the 1960s (which many cultural historians often bracket with developments in the early 1970s) can be described as the germination stage for health psychology. This was the period when there was widespread social change and public debate about social relations and social organisation. In the USA there were mass movements for civil rights and the rise of the women's movement. In Europe, there were student and worker uprisings in both the East and the West and there was renewed interest in Marxist and other critical ideas of the 'New Left'. In the former colonial world there was the breaking of imperial domination and the emergence of new radical theorists including those who were particularly concerned with the psychology of oppression and change, e.g. Steve Biko in South Africa, Frantz Fanon 
in Martinique/France/Algeria and Albert Memmi in Tunisia. Internationally, there was debate, especially among younger people, about the supposed materialism of mainstream culture and a growing interest in alternative ideas and lifestyles. These ideas were reflected in popular art, music and publications (see e.g., Lynskey, 2011).

Within psychology there was also debate about the nature of the discipline. This was especially the case within social and applied psychology which was particularly concerned about psychology's broader role in society. Within social psychology there developed what was subsequently labelled the 'crisis' with publications critiquing the limitations of dominant behavioural theories and attempts to find alternative approaches (see Lubek, 1993). Wexler (1983) in one of the earlier reflections on this crisis noted that in North America this debate was largely focused on "methodological critique and conceptual repair" (p. xv) rather than epistemological review.

In Europe there was a broader critique with a particular interest in both socio-political processes and in epistemological issues (see Parker, 1989; Lubek, 1993). For example, in 1972 Joachim Israel and Henri Tajfel published a collection on 'The context of social psychology: a critical assessment'. This included a strenuous challenge to mainstream social psychology by several researchers including Serge Moscovici who argued on the one hand against the 'scientism' of supposed objective psychology and on the other hand against the traditional focus on the individual and the neglect of social relations. Moscovici condemned what he described as the 'fetishism' of the excessive concern with methods which had historically been a defining feature of psychology. He also referred to the focus on the individual as being a reflection of capitalist ideology: 
"All that goes beyond individualism and all that diverges a little from a capitalist model enters by definition the domain of irrationality" (p. 22).

Instead he called for a new psychology of the social which would actively work to enhance human capacity. Moscovici also made a call for a turn to language which had been promoted by a range of other social scientists. For example, Peter Berger and Thomas Luckmann published their classic work on the social construction of reality in 1966 in which they argued that 'the great part, if not all, of everyday conversation maintains subjective reality" (Berger \& Luckmann, 1966). This work heralded a turn to language which began to build momentum in the 1970s when it was taken up by such psychologists as John Shotter (1975) who argued that "the meanings we express in our language and the way in which we act in our everyday practices are woven into one another" (pp. 37-38).

In the health realm there was also discussion about the nature of health and illness and the forms of healthcare. There was the emergence of popular interest in what became known as alternative healthcare which was initially confined to those who championed alternative lifestyles. There was also the re-emergence of clinical attention to psychosomatics or that field of psychiatry known as liaison psychiatry which was concerned with the role of psychological factors in physical illness. This was part of growing criticism about the role of medicine in healthcare and in society. For example, Ivan Illich published his work on iatrogenesis in 1974 in which he identified medicine itself as a major source of ill-health. This critique of the power of the medical profession was also taken up by sociologists (e.g. Freidson, 1970). Of particular importance was the beginning of a series of very influential publications by Michel Foucault not only on the nature of medicine (Foucault, 1965, 1974) but also on the nature of power and knowledge in society (Foucault, 1970). 
There was particular critique of the dominant medical approach to mental illness and attempts to develop more social forms of therapy in various community settings. Foucault's (1964) original work on madness and civilisation considered how the meaning of madness was not fixed but was connected to the particular historical period. Another influential figure was Tomas Szasz (1961) who argued that mental illness was a social construct created by the medical profession. These books had tremendous influence in challenging the dominant biomedical models of mental illness and of treatment.

There were also attempts to develop a more community-based approach to the care of people with mental health problems. This mood was evident in psychology in the election of George Albee to the Presidency of the American Psychological Association in 1970. It is useful to look back at his challenging critique of clinical psychology at that time. He began by drawing attention to the social bases of mental ill-health and called for a direct challenge to the current political establishment and social arrangements as a means of promoting mental health. As he argued about that time:

"We must realise that the terrible suffering that exists in our society among the disenfranchised, the poor, the havenots, can only be remedied by direct confrontation with the establishment, by the socialisation of our care-delivery systems, by the development of adequate tax-supported public facilities, staffed with competent BA-level interventionists using social models which can only be developed as creative people find out about the real problems ... The times are right for revolution!" (Albee, 1969).

These new ideas and social movements encouraged many social and clinical psychologists to begin to consider the broader potential role of psychology in society and in healthcare. 


\section{Early days}

The original enthusiasm for change in the 60 s and early 70 s was dampened by economic recession and moves by the state to draw back on any previous liberal reforms and to reassert a more conservative political agenda in the later 1970s. William Ryan (1976), the clinical psychologist who coined the term 'victim-blaming', noted the deliberate attempts of the US government at that time to water down the earlier social reforms and place the blame for social problems in supposed defects of the victims of social disadvantage. In Britain, Margaret Thatcher was elected Prime Minister in 1979 and quickly moved to introduce a range of measures to reduce the power of the organised labour movement. In civil society there was evidence of a turning away from collective forms of action to a greater self-absorption which led the U.S. novelist Tom Wolfe (1976) to term the 1970s as the 'me decade'.

Within North American social psychology there was the promotion of a number of social cognitive models/theories which supposedly addressed the crisis highlighted in the previous decade. Of particular note was the publication of Fishbein and Ajzen's (1975) foundational text on attitudes - Belief, attitude, intention, and behavior: An introduction to theory and research. In their preface the authors asserted their approach very clearly:

"Generally speaking, we view humans as rational animals who systematically utilize or process the information available to them. The theoretical structure or conceptual framework we have adopted assumes a causal chain linking beliefs, formed on the basis of available information, to the person's attitudes, beliefs, and attitudes to intentions, and intentions to behaviour" (p. vi). 
The focus of this reductionist theory of social psychological processes was on developing strategies to change individual behaviour by identifying and changing supposed problematic self-contained personal beliefs and perceived norms.

This period also saw the publication of Albert Bandura's influential Social Learning Theory (1977). This text argued that much of human behaviour was learned by modelling the behaviour of other people. As he stated in the introduction:

"Learning would be exceedingly laborious, not to mention hazardous, if people had to rely solely on the effects of their own actions to inform them what to do. Fortunately, most human behavior is learned observationally through modeling: from observing others one forms an idea of how new behaviors are performed, and on later occasions this coded information serves as a guide for action" (p22).

Noticeable in these new social cognitive approaches was the absence of any reference to the role of social structure or to issues of power and social change. Rather the aim was more to establish universal laws of individual human behaviour and behaviour change. However, the critical voices were still present in psychology, particularly within social and clinical/mental health psychology, and there was a steady stream of publications during this period voicing dissatisfaction with the whole positivist orientation of the discipline. Although this broader social critique was especially present in Europe there was also critique in North America and in the global south. A few examples will illustrate the mood. In Britain, Nigel Armistead (1974) edited a collection on 'reconstructing social psychology'. In his introduction he asserted: 
"This book has arisen out of our dissatisfaction with much of what is called psychology. That dissatisfaction is felt most acutely in relation to the lives we are leading and the world that we see around us. We feel that social psychology should be making some sense of our experience and that it doesn't: we feel disappointed" (p. 7).

Similarly, Nick Heather (1976) opened his short introduction to 'radical perspectives in psychology' with the call:

"If the criticisms of psychology and psychiatry presented in this book are radical, it is because they challenge the assumptions of those disciplines at the root. And if changes in psychology and psychiatry are urged as part of a larger, radical change in society, it is because that society needs to be transformed at the root" (p. 9).

In North America, Phil Brown's (1974) political critique of psychology was in many ways a lonely voice. He began his short polemical book with these words:

"Psychology is more than just a professional field of work. It is also a codified ideology and practice that arises from the nature of our capitalist society and functions to bolster that society" (p. 1).

While these voices were most definitely in a minority in the advanced capitalist world, in developing nations there was also anger at psychology's accommodation with the institutions of the powerful. Ignacio Martin-Baro who was a psychologist and priest from El Salvador enthusiastically championed these critical ideas throughout the 1970 s and 1980 s. He strongly criticised the 'scientistic mimicry' of North American psychology and its 
individualism. He developed what he termed a liberation psychology. In his posthumously translated work he argued:

"The problem with individualism is rooted in its insistence on seeing as an individual characteristic that which oftentimes is not found except within the collectivity, or in attributing to individuality the things produced only in the dialectic of interpersonal relations. Through this, individualism ends up reinforcing the existing structures, because it ignores the reality of social structures and reduces all structural problems to personal problems" (Martin-Baro, 1986/1994, p. 22).

Martin-Baro further argued that psychologists should also adopt the 'preferential option for the poor' and work with the marginalised and the oppressed to develop strategies of change and opposition to repression.

In Africa we had the development what can be termed the psychopolitics of Frantz Fanon and Steve Biko (see Hook, 2004). These theorists argued for the need to consider how political power permeated everyday social relations and sense of being.

The 1970 s also saw the publication of a series of reports on the social distribution of health and illness. In the United States, the Surgeon General published a series of very influential reports on the health impact of smoking and its contribution to explaining social variations in health. In addition, the Department of Health \& Human Services published several reports highlighting black/white differences in health and calling for a need for targetted interventions to change unhealthy behaviours. In Britain, the Black Report on social inequalities in health in Britain which was originally commissioned in 1977 was finally published in 1980 (DHSS, 1980). It clearly described the association between lower social 
class and ill-health and identified four main explanations - artefact, genetic, cultural/behavioural and structural/material. Although there was no intention by the report's authors to separate out the explanations, in practice the focus was largely on the behavioural/cultural. This orientation accorded with the growing health promotion ideology with its focus on individual behaviour change as the path to a healthier society. This contemporary victim blaming approach was evident in the British government's report 'Prevention and health - everybody's business' (DHSS, 1976).

A focus on individual responsibility, together with the publication of a series of key texts on social cognition with its promise of a scientific approach to individual behaviour change provided the social and intellectual context for the formal establishment of health psychology. In the 1970s the potential of a new field of research was increasingly discussed in US universities, especially by social and clinical psychologists (Stone, 1991). In 1979 the first textbook of health psychology was published by Stone and his colleagues following a series of specialist seminars. In his introductory chapter Stone proudly stated:

"The term health psychology is a new one. No book before this has borne that name. Until a year or two ago, no school trained health psychologists. In the professional organisations of psychologists, no provision was made for bringing together psychologists who were interested in the study of health, health-seeking behaviour, or the health care system" (p. 1).

In the preface to this textbook the editors provide several pointers to how the field would evolve. There was excitement about the potential contribution of a new discipline which could develop psychology's contribution to promoting health: 
"Their [seminar participants] active interest enhanced our excitement about the possibilities for the new field and engendered a determination to explore those prospects more fully. As the core faculty in this new program, we saw the need for a book that would fully investigate what psychologists had done and what they could do to make their expertise more widely available for the resolution of health problems" (p. xi).

The boundaries of the field were still unclear and this was reflected in the edited form of this book with only a loose organisation into four parts: Health psychology in historical and comparative perspective, Psychological aspects of illness and patient care, Approaches to problems of health care providers, and Trends and new directions in health psychology. From the outset the authors were not concerned with simply investigating psychological aspects of health psychology but with establishing a new discipline and profession. Naturally part of this was the establishment of a professional body. In 1978 the Division of Health Psychology was established within the American Psychological Association. Joseph Matarazzo, who was very influential in defining the new discipline, forcefully set out its aims in one of his keystone statements:

"We must aggressively investigate and deal effectively with the role of the individual's behaviour and lifestyle in health and dysfunction. [...] Furthermore, representatives from many segments of our society are increasingly looking to the science and profession of psychology for help with this problem" (Matarazzo, 1982). In this extract, he states that the field (as both a science and a profession) emerged in response to the demands of various representatives of society - by which he meant not only the large numbers of people who were dissatisfied with traditional medical care but also the 
state which was alarmed at the escalation of healthcare costs. Furthermore, Matarazzo called on this new discipline not to be cautious but 'to deal with' these problematic individual behaviours. This is the voice of confidence and truth which historically has typified those in positions of power.

In 1983, at a specialist meeting convened in Arden House in upstate New York it was agreed that "health psychology is a generic field of psychology, with its own body of theory and knowledge, which is differentiated from other fields of psychology" (Friedman, 2002). But there were other social science disciplines such as sociology and anthropology involved in the debate about the nature of health and illness but the focus of health psychology matched with the preferred orientation of government funding agencies. Thus it is noticeable how in the Stone et al textbook they devote considerable effort to distinguish health psychology from these neighbouring social/health disciplines. The distinctiveness of health psychology is a common theme often introduced in the introductory chapter of the growing number of textbooks which began to be published from the mid-1980s.

\section{Consolidation}

The following $20-30$ years was a period of consolidation of health psychology as both a discipline and a profession. This was a period that saw the collapse of the various communist regimes in the East and the growth of neo-liberal ideology in the West - the socalled 'end of history' (Fukuyama, 1992). This descriptor was perhaps fitting for health psychology at that time as the emphasis was more on refining its tools and ideas rather than engaging in substantial theoretical or methodological innovation. It was the period when standard research methods were established and professional standards agreed. With so 
much disciplinary demarcation occurring there was little time for critical debate about the nature of health psychology.

In particular, a limited range of theories (Health Belief Model, Theory of Reasoned Action, etc.) and methods (questionnaires and standardised scales) became established as the accepted approach. The study of the relationship between attitudes/cognitions and behaviour remains at the centre of health psychology. This narrowing of vision is not unusual in the development of any discipline. There is a desire and an enthusiasm to assert the place of the new discipline among the range of other disciplines, especially within healthcare which is dominated by medicine with its mind-body dualism and its limited concern with social issues. The promotion of the so-called biopsychosocial model of illness was health psychology's way of cautiously expanding the basic biomedical model and asserting psychology's role in healthcare.

A number of textbooks began to more clearly define the field of health psychology. Although each textbook tried to be distinctive, over time they began to agree on common issues and approaches. After Stone et al's initial overview volume, the first major textbook was that by Gatchel and Baum (1983). In a forward to the second edition Jerome Singer (Gatchel \& Baum, 1989) clearly identified the importance of the textbook in shaping a field or discipline:

"To the extent that textbooks now copy the format of previous successful books, texts that follow theirs would adapt their organisation, and, in a pragmatic fashion, the field would be defined by what was in the textbook" (p. viii). 
But it was not simply the organisation of the subsequent textbooks. If we look at the key North American health psychology textbooks since then we can see a number of common themes that are stressed in the prefaces and introductions.

\section{Tone}

Frequently the textbook authors refer in their prefaces to excitement as if they wanted to maintain some of that excitement which was apparent in the heady days of the 1970s and early 1980s (Stone et al, 1979). Friedman (2002: xvi) recalled the "exhilaration" engendered by the 1983 Arden House conference in upstate New York. He continued:

"I wrote this text with the hope that it captures the excitement of these dreams come to fruition" (p. xvi).

This was a new field of research and practice, especially for students who were deciding which area of psychology to specialise in and the textbook authors wanted to highlight this excitement as a means of persuasion. In her 'Preface to students' in the first edition of her textbook, Taylor (1986) stated:

"The final goal of this book is to convey a sense of excitement of the field of psychology. ... Health psychology is a field that never ceases to fascinate students. If this book is successful in conveying some of that excitement, then it will have achieved its purpose" (p. ix).

Similarly, Sarafino (1990) in the preface to the first edition of his textbook also wanted to convey this excitement: 
"The field of health psychology is enormously exciting, partly because of its relevance to the lives of those who study it and of individuals the students know or will work with in the future. The field is also exciting because it is so new, and researchers from many different disciplines are finding fascinating and important relationships between psychology and health" (p. vii).

This excitement was presented in almost revolutionary terms by Sheridan and Radmacher (1992). The very title of their textbook makes this explicit - "Health psychology: Challenging the biomedical model". They begin their preface by dismissing the dominant biomedical approach to illness and continue:

"We should expect that in the early stages of this revolution, a wild variety of challenges to the old model will be put forth. Some of these alternatives will prove to be solid and will take their place as part of the structure of the new paradigm. Others will fall away and be forgotten, or be exiled to the realm of cookery or even of quackish views" (p. viii).

They continue in this almost messianic tone:

"Eventually there comes a time when the wheat must be separated from the chaff, when someone has to take on the task of presenting a coherent view of the current status of the new model. This is what we have tried to do in the present work" ( $p$. viii).

Thus the textbook authors want to present this air of excitement but still develop a 'coherent view'. The repeated reference to excitement betrays a certain uneasiness about the field while some of the calls to the students are couched in a semi-religious tone 


\section{Content}

Although the textbooks varied in their content increasingly they covered similar topics, sometimes in a different order or with a different emphasis. Taylor's work placed somewhat more emphasis on health promotion while others considered more the psychological aspects of illness. Sheridan and Radmacher (1992) placed the biopsychosocial model at the centre of their text. They saw this as a direct challenge to the dominant biomedical model. They described this challenge as follows:

"The main features of present day biomedicine could be seen by the turn of the century. The biomedical model took the art of medicine and founded it squarely in the biological sciences. This laid the foundation for many great accomplishments, many of the early twentieth century's most deadly biological killers have now been subdued. But the easy medical conquests are not but glorious memories, and biomedicine, along with its practitioners, is challenged and subjected to sceptical inquiry at every turn. One of the most important challenges comes from those, like the present authors, who advocate a biopsychosocial model" (p. vii).

In her sixth edition of Health Psychology Taylor (2006) argues that this challenge has become widely accepted:

"When I wrote the first edition of Health Psychology nearly 25 years ago, the task was much simpler than it is now. The health psychology field was relatively small. In the past 25 years, the field has grown steadily and great research advances have been made. Chief among these developments has been the use and refinement of the biopsychosocial model" (p. xiii). 
Similarly, Friedman (2002) in his second edition used the biopsychosocial model to "attempt[s] a conceptual integration rather than a simple litany of research findings" (p. xv)

The biopsychosocial model had evolved from the previous critique of the biomedical model by Engel (1977). However, although the radical pretensions of the biopsychosocial models were widely trumpeted, in practice this model was restricted by its location within the traditional input-output engineering model that was dominant in health psychology (see Ogden, 1997; Stam, 2004).

\section{Self improvement}

One of the largest forms of popular literature is self-help or self-improvement books which have grown rapidly in popularity over the past fifty years (Dolby, 2005). Although health psychology textbook authors want to distinguish themselves from these 'unscientific' works, they generally argue that the research reported provides a scientific approach to selfimprovement. A consistent theme in all of the textbooks is the steps that individual readers can take to improve their health. Sarafino (1990), in his preface, sets this emphasis within the context of the individualistic tradition of American culture:

"The first wealth is health' wrote the poet/philosopher Ralph Waldo Emerson in the nineteenth century. Although people have probably always valued good health, Americans today are becoming increasingly health conscious. This heightened consciousness generally reflects two beliefs. One is that we can do things to protect our health and prevent illness. The second is that being sick is usually unpleasant as Emerson put it, 'sickness is poor-spirited, and can serve anyone'. If a person's health problem is serious, it can be quite distressing to the patient and his or her 
family and friends. These beliefs underlie psychologists interests in helping people behave in ways that promote wellness, adjust to health problems that develop, and participate effectively" (p. vii).

Brannon and Feist (1990) also emphasise how individual responsibility is increasingly important for health:

"At the beginning of the twentieth century, most serious illnesses were caused by contact with viruses and bacteria. People had little individual responsibility for preventing diseases because those microorganisms were nearly impossible to avoid. Today, most serious diseases occur as the result of individual behaviors, or failures to behave" (p. x).

The last phrase is almost an admonishment to the reader. This tension between a scientific textbook and a self-improvement book is a consistent theme. Frequently, there is a message to the student readers that they can personally use the ideas in the textbook to improve their own health. Taylor (1986) emphasises this in the preface to her first edition:

"The material in Health Psychology can be practically applied in a variety of fields. Consequently, practical applications are emphasised throughout the book so that students can see not only how the material can be useful in their lives generally but also can be integrated into future careers" (p. vii).

Similarly, Sarafino (1990) states in his message 'to the student':

"Two things that will probably make health psychology interesting to you, (1)the material is personally relevant and (2) many of the things you learn can actually be applied in your everyday life" (p. xi). 
In case the student does not grasp the importance of this advice, Sarafino deliberately stresses 'personally relevant' and 'applied'.

The books often use a mix of approaches to get this message of personal relevance across. For example, Brannon and Feist (2000) boast in the preface to their $4^{\text {th }}$ edition:

“...new features include chapter-opening questions and 'Check your health risks' box, and a 'Becoming healthier' box. The purpose of these additions is to actively engage readers in the process of acquiring health-related information to enhance their personal well-being" (p. x).

Other textbook use similar approaches.

\section{$\underline{\text { Scientific }}$}

A common theme is that health psychology is scientific. In the preface to the Second edition of Health Psychology Taylor (1991) stresses this theme:

"My goal in the second edition of this text is to convey the increasing sophistication and complexity of the field in a manner that makes it accessible, comprehensible, and exciting to undergraduates, without compromising the scientific nature of the field" (p. xiii).

Here she is emphasising that while the field, and particularly her presentation of it, is exciting, it is still scientific. She is separating the discipline from more populist accounts of psychological aspects of health and affirming the traditional approach to scientific inquiry:

"My goals guiding the preparation of this edition were several. The first concerns the nature of the content. Like any science, health psychology is cumulative, 
building on past research advances to develop new ones. Accordingly, I have tried to present not only the fundamental contributions to the field, but the current form research in these issues takes" (p. xiii).

Taylor later re-emphasises this point:

"Health psychology is a science, and consequently it is important to communicate not only the research itself, but some understanding of how studies were designed and why they were designed that way. The role of research methods and theories to understand health-related issues is consequently a major theme of the book" ( $p$. xiv).

This is a theme that Taylor repeats in subsequent editions of her book. Not only is she clearly distinguishing health psychology from non-science but justifying yet another edition 'because the field is growing so rapidly' (p. xiv). The approach to science is uncontested but rather it is presented as the steady accumulation of knowledge.

\section{$\underline{\text { Theoretical eclecticism }}$}

The textbook authors consistently emphasise that health psychology is not wedded to any single theoretical orientation. Rather, in many ways it is a 'field' drawing on various subdisciplines within psychology. By supposedly eschewing any orientation the authors present themselves as being impartial. For example, in the first edition, Taylor states:

"Since health psychology is taught within all areas of psychology (clinical, social, cognitive, physiological, learning, developmental) material from each of these areas has been included in the text, so that it can be accommodated to the orientation of each instructor. The book has no commitment to a particular theory. Instead, it 
reviews a variety of perspectives as they become relevant to the particular health problem under discussion" (p. vii).

Similarly, Sarafino (1990) presents his selection of material as being impartial:

"The psychological research cited reflects an eclectic orientation and supports a variety of behavioural, physiological, cognitive and social/personality viewpoints. In addition, gender and sociocultural differences in health and related behaviours are addressed at many points in the book. In these ways, the book presents a balanced view of health psychology that is arguably in the mainstream of current thinking in the field" (p. p. viii).

The reference to balance and the mainstream suggests a movement towards what is proper health psychology. There is no reference to any critique of the mainstream approaches. The author is impartially setting out the truth.

Sheridan and Radmacher (1992) are more explicit about the process of deciding what to include and what to exclude without 'unduly narrowing the scope' of the field:

"The rapid growth and diversity of our field makes it impossible for anyone to have a full grasp of all the traditions that have influenced health psychology. People of many contending persuasions have contributed to the development of health psychology. They range from strict behaviourists at one pole to those interested in holistic medicine at the other. Each of them, to one degree or another, has contributed to the development of a new perspective on health. It was a major task to decide which of the contributions should be part of the corpus of health 
psychology. We had to be selective, but we tried to do so without unduly narrowing the scope of our topic" (p. viii).

They 'had to be selective' but the criteria they used are not clear. Rose (1996) in his critique of the growth of psychology notes how minority voices are often derided and excluded from debate. They are considered illegitimate. Thus these textbooks do not include any critical voices, qualitative accounts of illness experience and limited discussion of social and cultural variations in health and illness.

\section{Mainstream approach}

The dominant form of health psychology that is represented in these textbooks is premised upon instrumental knowledge which is especially concerned with explaining patterns of behaviour and developing individual behaviour change strategies. It generally adopts the classic positivist approach to science with the testing of various explanatory models. The emphasis remains upon objectivity and distance. This so-called scientific approach can adopt all the trappings of natural science to assert its objectivity. It is particularly concerned with measurement of variables and detailed statistical analyses.

This concern with objective methods has of course been one of the defining characteristics of the whole discipline of psychology. A range of critics have referred to this excessive concern with methods as methodolatry (Bakan, 1967), the cult of empiricism (Toulmin \& Leary, 1985), the methodological imperative (Danziger, 1985), and methodologism (Teo, 2005). Smith (1997) has provided a good summary of the influence of this approach within psychology which he notes was "distinctive as a science because of the degree to which it defined itself by its methods rather than by its subject matter" (p. 639). Historically, a major 
challenge for psychology, unlike other sciences, has been that its subject matter is the concern of everyday conversation and so by clothing it in the language of sophisticated technique and statistics it was hoped to acquire the high status of the other sciences. This would seem to be particularly apposite for health psychology.

A particular focus in this scientific approach has been on the character of the individual whether in terms of individual attitudes and beliefs or of human experience which are often described in terms of deficits. The preference is for a form of the machine metaphor which characterises human action in terms of inputs and outputs (cf. Sarbin, 1986). This approach also tends to define health psychology with reference to the traditional medical model with its clear separation of mind and body to which has been added the social (meaning immediate social relations) in the biopsychosocial model.

The focus on the individual has tended to separate health psychology from discussion about the importance of the broader social and political context and to promote a concern with individual change. The many contradictions in human thought and action are smoothed in detailed statistical analysis and instead the search tends to be for universal laws of behaviour. Historians of psychology as a whole have commented that this tendency to focus on methods conceals a certain unease underlying the discipline (Smith, 1997).

The tendency is to extract the individual from their social world and to focus on developing individual change strategies to correct certain supposed individual deficits. This process has been described by Nikolas Rose (2007) as the technology of individualization: "In liberal democratic rationalities of government, abstract notions of the freedom of the individual are accompanied by the proliferation of rationalized practices that seek to shape, transform and reform individuals". In doing so, professional health psychology seeks to follow the 
tenets of the scientist - practitioner model defined by clinical psychology (see Murray, Nelson, Poland, Maticka-Tyndale \& Ferris, 2004).

This approach presupposes access to specialist knowledge and skills which not only separate the health psychologist from the lay audience but more clearly aligns her/him with other health professionals. This distinction is accentuated by the adoption of various trappings of more established professional groups. Part of this process of defining a profession involves drawing up syllabi and establishing accreditation guidelines such that we can define who is qualified in health psychology. It also means policing the boundaries such that unacceptable theories, methods and practices are sidelined and often ridiculed (see Rose, 1996).

There is also identification with other health professions, especially with medicine. Many health psychologists have found employment in medical schools often teaching medical students and other health professionals. There is involvement in the interdisciplinary endeavour known as behavioural medicine. While this opens up opportunities for interdisciplinary work it also has the risk of downplaying discussion about broader sociopolitical issues and focuses the gaze more firmly on the individual. Instead, the concern is more with psychological aspects of medically defined diseases and the contribution of psychology in enhanced treatment models. In practice, psychology becomes co-opted by the dominant medical model (Murray \& Chamberlain, 1999).

These scientific and scientist-practitioner approaches are the dominant orientations which have led to health psychology establishing itself as influential in a range of healthcare arenas. This preference for a narrow range of standardised approaches which do not challenge the ideas of the dominant discipline/profession (in this case biomedicine) is not 
unusual in the early stages of any discipline. It is a means by which a new discipline asserts its identity as distinct and as offering a particular contribution to both knowledge and practice.

\section{European perspectives}

In Europe the growth of health psychology occurred somewhat later than in North America and drew much of its inspiration from the work published there. Indeed, the organisers of original conferences of the UK Health Psychology Section and the European Health Psychology Society always prided themselves in having North American keynote speakers. In some ways this was the reverse of Freud's famous quip to Jung on arriving in New York about the importation of psychoanalytic ideas to North America: "Little do they know, we are bringing the plague" (see Fairfield, Layton \& Stack, 2002:1). Only this time it was the importation of the positivist approach within health psychology to Europe.

European health psychology textbooks were also later and fewer. Although, they often reviewed similar research, to varying degrees they adopted a more critical and social stance to the field. This reflected much greater engagement with some of the earlier debates within social and clinical psychology previously described and a greater acceptance of more social democratic ideas with an awareness of the importance of structural factors which were clearly identified in the very influential Black Report on health inequalities (DHSS, 1980). At least three distinct themes are apparent in the most popular textbooks. [I have only considered texts published in the UK and have included the work by Lyons \& Chamberlain (2006) since their book was initiated while Lyons was resident in the UK and although both authors are currently located in New Zealand they have had substantial involvement in UK and European debates]. 


\section{$\underline{\text { Reflexivity }}$}

There is a greater reflexivity about the nature of theories and methods. Unlike North America textbooks which regarded theories as models to be tested by the collection of data, there is greater awareness of the contested nature of theory. Ogden $(1996,2004)$ eschews a preface in her textbooks but instead includes a substantial closing reflection on the field, and her organisation of it in the textbook. The length and content of these reflections vary over the editions but there is a consistent degree of self-criticism. She (Ogden, 2004) introduces self-doubt into the more progressive view of science paraded in North American texts:

\footnotetext{
"Health psychology assumes that these shifts in theory represent improvement in our knowledge about the world. We know more than we did a hundred years ago and our theories are more accurate. However, perhaps such changes indicate different, not better, ways of viewing the world. Perhaps these theories tell us more about how we see the world now compared with then, rather than simply that we have got better at seeing the world" (p. 398).
}

In the most recent textbook Ogden (2013) titles her closing chapter 'Being critical' and considers further the need for theoretical and methodological reflection.

Marks, Murray, Evans \& Willig (2000) also adopt a more questioning stance. Their preface introduces a concern about the dominant theories and methods in the field:

"It aims to dig below the surface to expose the underlying theoretical assumptions of the field and critically to analyse its methods, evidence and conclusions" (p. ix). 
In the second edition (Marks, Murray, Evans, Willig, Woodall \& Sykes, 2006) this becomes more explicit with reference in the preface to "critical health psychology" as underlying the "entire book" (p. xi).

Similarly, Lyons and Chamberlain (2006) in their "Setting out: using this book" list a series of criticisms in an almost litany format:

"We are critical of the way it [mainstream health psychology] unreflexively continues the traditions of mainstream psychology, assuming that psychological factors have a real existence, that they can be meaningfully and accurately measured, that statistical findings have meaning be virtue of their significance levels and that findings (almost) have the status of general laws" (p. 1).

This reflexivity also applies to methods of research. Ogden (2004) raises a series of questions:

"How do we know that our methods are separate from the data we collect? How do we know that the objects of research (beliefs, emotions and behaviour) exist prior to when we study them" (p. 398).

Rather than a proscribed list of acceptable methods which can provide access to the world there is greater enthusiasm for multiple methods. Marks et al (2011) introduce an extensive A to $Z$ of methods. There is also a desire to challenge the supposed objective stance of the scientist. For example, Lyons and Chamberlain (2006) note how in 'mainstream' texts:

“The values of 'positivist' science and the 'detached' observer are taken for granted, and there is no attempt to examine the assumptions and values which underlie the research presented in the texts" (p. 2). 
Instead they argue for the need to be:

"reflexive about ourselves, our approaches and our field, questioning our own values and assumptions" (p. 3).

\section{Language}

A second frequent theme is an attempt to deal with the everyday language of health and illness. This reflects a growing enthusiasm for qualitative research methods and an interest in understanding the actual experience of being health and of being ill (see also Lyons, 2010; Smith, 2012, Stephens, 2012). Marks et al (2011) argue for "more in-depth understanding not only of the complexities of human behaviour, but of the lived experience of health, illness and health care" (p. x). The most recent popular UK textbook is that by Morrison and Bennett $(2006,2009,2012)$. In the second edition they note that there was:

"increased use of qualitative studies and personal experiences in an attempt to make the experiences of trying to maintain health or becoming ill more personal and accessible, for example, through the use of case studies in some chapters" (Morrison \& Bennett, 2009, p. xxi)

This concern with the role of language in constructing our everyday reality and experience challenges the traditional separation of mind and body. In their listing Lyons and Chamberlain continue:

"We are critical of the way in which health psychology all too readily adopts the premises and assumptions of biomedicine, and the ways in which its findings promote biomedical understandings, albeit in the guise of a 'biopsychosocial' approach, a vague entity with many meanings" (p. 1). 


\section{Society and health}

A third major theme in European textbooks is the greater awareness of the social location of health and illness. In the preface to first edition of their textbook, Marks, Murray, Evans and Willig (2000) explicitly state the need for health psychology to be socially located:

"Health psychology is a richly interdisciplinary field requiring an understanding of the cultural, socio-political and economic roots of behaviour and experience" (p. ix).

Their first three chapters expands this theme and considers "Health psychology in context" - specifically disciplinary, socially and culturally. Although this book adopts a focus on health promotion it is less concerned with individual change and more in social and community change:

"Health psychology has a crucial role to play in helping the development and evaluation of health promotion interventions. Psychologists will be doing this in close collaboration with communities, other professionals, and policy makers" (p. ix).

In the second edition this more social approach becomes more explicit:

"Against the view that health behaviours are an individual responsibility, governed by freely taken choices, a large amount of the burden of disease is the product of a toxic environment that pushes people towards health-aversive behavioural choices" (p. ix)

Similarly, Lyons and Chamberlain (2006) complain:

"We are critical of the lack of consideration in health psychology of the social context within which health and illness are experienced and understood ... health and illness 
are located at the individual level, and social, structural and cultural perspectives are not taken into account" (p. 1).

Morrison and Bennett (2006) also refer to the importance of social context:

"We believe that in addition to covering mainstream health psychology topics such as health and illness beliefs, behaviour and outcomes, topics such as socioeconomic influences on health, biological bases, individuals and cultural differences and psychological interventions in health, illness and healthcare, are all essential to the study of health psychology" (Morrison \& Bennett, 2006, p. xix).

In the second edition (Morrison \& Bennett, 2009) they add that they have:

"increased our emphasis on critical psychology, in terms of casting a more macro-eye over social, environmental and cultural influences on health and illness" (p. xxi).

Being aware of the importance of the social critique of health, Morrison and Bennett (2013) refer to the call for health psychology to broaden its approach to encompass sociocultural, economic and political aspects psychology (Murray \& Campbell, 2003) in their concluding comments to their third edition:

"This book has acknowledged this need in a whole chapter addressing social inequalities in health and integrated elsewhere in the book are many of the criticisms targeted at mainstream health psychologists by critical health psychologists" (pp. 500-501)

Similarly, in the most recent edition of her textbook Ogden (2013) includes a new chapter on health inequalities with discussion of variations in social class, gender and geography. 
Flowing from this engagement with the social are concerns with issues of power and ways of promoting health through social action to challenge existing power relationships which assume greater urgency as the current economic recession bites. For example, Marks et al (2011) state in their most recent preface:

"As the gaps between the 'haves' and the 'have-nots' widen, and the population is ageing, the impacts of learned helplessness, poverty and social isolation are increasingly salient features of society. The contemporary emphasis on improving health care - a significant and worthy task - at times is little more than tinkering in a way reminiscent of Nero fiddling while Rome burnt" (p. xii).

\section{Critical approaches}

While the more critical approaches within health psychology have grown over the past ten years especially in Europe, there were, of course, minority voices who argued for the adoption of more critical and qualitative approaches within the field from its earlier days. In the 1970 s there was the classic work by Claudine Herzlich (1973) on social representations of health and illness. Drawing upon the European tradition of social representation theory this work was largely ignored in North America which preferred to develop its own cognitive approach to studying representations of health and illness (see Murray, 1990). In the 1980s there was the broader turn to language (see Potter \& Wetherell, 1987; Parker, 1989) which gradually began to have an impact in health psychology. Almost at the turn of the century Murray \& Chamberlain (1998) produced a special journal issue on qualitative research in health psychology. In their introductory remarks they emphasised the need to go beyond description: 
"It should be emphasised that qualitative research does not merely consist of interviews followed by descriptive content analysis, but involves much more [...] There is an urgent need for health psychologists to develop a more sophisticated understanding of theory underlying qualitative research, as well as its premises and practices (p. 294).

In the following year there was the publication of Qualitative health psychology: Theories and methods edited by Murray and Chamberlain (1999) which begins with the comment:

"concerns about the adequacy of natural science as a model for health psychology has led to increasing criticism of the use of quantitative methods within health psychology" (p. 6).

That book contained a variety of different approaches to qualitative research and, as the editors emphasised, it was:

“intended to provoke more debate and not to provide finished answers. It is designed to encourage reflection on and reassessment of the quantitative approach which has dominated our discipline and to consider alternative perspectives" (p. 13).

The following year saw the publication of Rethinking health psychology by Michelle Crossley (2000). In this she clearly distinguished between 'mainstream' and 'critical' health psychology or to use Habermas's (1971) terms 'scientific' and 'hermeneutic' approaches. The latter she describes as a 'gradually emerging voice' (p. 1).

Over the past decade such critical ideas have attracted greater interest as evidenced by the convening of specialist meetings and the publication of special journal issues which attempt to develop a more critical approach to the discipline and to consider alternative research 
methods. There was the publication of the edited collection Critical health psychology (Murray, 2004) which is described in its introduction as:

"provid[ing] an outline of the important issues within a revitalised health psychology: one that does not adopt a scientistic objectivist attitude but one that is much more reflexive and socially engaged" (p. 11).

Unlike much of mainstream psychology this critical approach is not unified but rather promotes a range of methods and theories. Underlying this critique, however, there is a broader concern with values - primarily, what is health psychology for and who does it serve (e.g. Murray et al, 2004).

A common aim of the critical orientation within health psychology has been to reorient the discipline away from a focus on measuring individual characteristics to a concern with more dynamic social psychological, socio-political and socio-cultural processes. It begins with an awareness of the changing socio-historical period within which we are located. Unlike, more mainstream approaches which is concerned with fixity, the critical approach accepts the fluidity of concepts but also realises the need to, as it were, take a stand. The critical approach is aware of the social contradictions between the massive accumulation of wealth in the hands of the few over the past decades but at the same time the massive levels of poverty that continue to exist. It is aware of the increasing evidence of social instability in our world; the break-up of traditional social relations and decline of traditional forms of community and social solidarity; the increase in mass migration of ethnic groups, etc.

Critical health psychology builds upon the broader critique of psychology. Rather than separating the individual out from social relations a critical approach intertwines the 
individual within those social relations. Health and illness are viewed firmly as part of these changing social relationships. Their character is determined both by the material conditions of everyday life but also by the character of our symbolic worlds (Ogden, 1997, 2003).

Critical researchers connect with that broader body of critical social theory that has developed over the past generation. Rather than accepting the individualisation that is implicit within much of contemporary psychology and the accepting of approaches that reinforce a neo-liberal ideology, critical perspectives connect the individual with the social and locate the work within a social justice framework. They engage with a wide range of critical ideas from discursive psychology on the one hand and other social science disciplines on the other. They argue that health psychology exists in a certain socio-historical context which raises questions about how research questions are defined and how they are investigated. Of particular interest is the role of power in shaping health and illness and how power permeates our everyday relationships within various healthcare and social arenas. The increasing awareness of these ideas throughout the discipline illustrates how critical ideas can grow in influence as they chime with changing socio-historical circumstances (Murray \& Poland, 2004).

In terms of methods, the critical orientation emphasises that these are always subservient to the task. While critical researchers have historically championed qualitative methods they are aware that methods are not fixed and that we should always develop and explore new methods. At all times critical researchers are attentive to different interpretations (see Willig, 2012) and how these can contribute to enhancing health and wellbeing. They reflect on the purpose of the research, how the research question is developed and their own position in the research process. 


\section{Not the end}

These different approaches within health psychology have changed over the history of the discipline and reflect the importance of the wider socio-political context within which any discipline works. In the 1970s when health psychology was developing there was sustained debate about giving people responsibility for their own health. In the UK there were classic reports about social inequalities in health which identified the importance of structural factors but these were sidelined and the focus was more on changing individual behaviour.

Forty years later as we enter a much more extensive world economic crisis these debates are coming to the fore again only this time the response of health psychology can be more sophisticated. Within a world of widening social inequalities, wars, natural disasters, and mass migration it is increasingly difficult for health psychology to maintain a disinterested stance. At times like this it is increasingly important for any discipline to both engage in critical reflection about theories, methods and values but also to engage in the broader public debate about the nature of our work. As the journalist Robert Fisk recently commented with reference to the Arab uprisings: "There is no 'end of history"” (Fisk, 2011).

In a world of evidence based practice there will be increasing pressure on health psychology to demonstrate its worth to funding agencies. From a traditional perspective this will involve extensive participation in randomised controlled trials. But from a critical perspective this requires greater reflection on the character of our practice and greater collaboration with groups and communities in a process of subversion and challenge to promote health and wellbeing. While these are challenging times they also open up tremendous opportunities for debate about our theories, methods and practices. 
Health psychology is not the 'steady accumulation of knowledge' but rather a process of inquiry and action that is socially immersed. Rather than a focus on more sophisticated statistical models there is a need for greater engagement with social and social psychological theory which will enable us to reflect upon the nature of our interpretations. As part of this reflection there is a need for a reassessment of the nature of science not as some objectified body of evidence but rather as a means of understanding the complexity of our existence and developing collectively better ways of living together. In Europe it is apparent in the textbooks that there is a willingness to engage in this broader debate. One challenge is in some ways to follow in Freud's footsteps and to begin to import this new plague of critique into North American health psychology. Maybe George Albee's (1969) early rallying cry will also gather new support in our changing world. 


\section{Acknowledgements}

Parts of this paper were initially presented at the European Health Psychology Society conference in Cluj, Romania in 2011. I would like to thank the organisers of that conference for their generous invitation and support. I would also like to acknowledge the very useful comments I received on earlier drafts not only from the anonymous reviewers but also from Ari Väänänen and Antonia Lyons. 


\section{Books cited}

\section{U.S. textbooks}

Brannon, L., \& Feist, J. (1992). Pacific Grove, CA: Brooks/ Health psychology: An introduction to behaviour and health, Second edition. Cole.

Friedman, H.J. (1989). Health psychology. New Jersey: Prentice Hall.

Friedman, H.J. (2002). Health psychology. Second edition. New Jersey: Prentice Hall.

Gatchel, R.J., Baum, A. (1983). An introduction to health psychology. Reading, MA: AddisionWesley.

Gatchel, R.J., Baum, A., \& Krantz, D.J. (1989). An introduction to health psychology. Second edition. New York: McGraw Hill.

Sarafino, E.P. (1990). Health psychology, Biopsychosocial interactions. New York: Wiley.

Sarafino, E.P. (1994). Health psychology, Biopsychosocial interactions. Second edition. New York: Wiley.

Sheridan, C.L., \& Radmacher, S.A. (1992). Health psychology: Challenging the biomedical model. New York: Wiley.

Stone, GC, Cohen F, Adler NE, \& Associates (1979) Health psychology - a handbook. San Francisco, CA: Jossey-Bass

Taylor, S.E. (1986). Health Psychology. New York: Random House

Taylor, S.E. (1991). Health psychology, Second edition. New York: McGraw-Hill

Taylor, S.E. (2006). Health psychology, Sixth edition. Boston: McGraw-Hill 
U.K. textbooks

Lyons, A.C., \& Chamberlain, K. (2006). Health psychology. A critical introduction. Cambridge: Cambridge University Press.

Marks, D.F., Murray, M., Evans, B., \& Willig, C. (2000). Health psychology: theory, research and practice. London: Sage.

Marks, D.F., Murray, M., Evans, B., Willig, C., Woodall, C., \& Sykes, C.M. (2005). Health psychology: Theory, research and practice. Second edition. London: Sage.

Marks, D.F., Murray, M., Evans, B., \& Estacio, E.V. (2011). Health psychology: Theory, research and practice. Third edition. London: Sage.

Morrison, V., \& Bennett, P. (2006). An introduction to health psychology. Harlow: Pearson.

Morrison, V., \& Bennett, P. (2009). An introduction to health psychology. Second edition. Harlow: Pearson.

Morrison, V., \& Bennett, P. (2012). An introduction to health psychology. Third edition. Harlow: Pearson.

Ogden, J. (1996). Health psychology: A textbook. Buckingham: Open University Press.

Ogden, J. (2007). Health psychology: A textbook. Fourth edition. Maidenhead: Open University Press.

Ogden, J. (2012). Health psychology: A textbook. Fifth edition. Maidenhead: Open University Press. 


\section{References}

Albee, G.W. (1969) Who Shall Be Served? My argument with David Shakow. Professional Psychology, 1, 4-7.

Armstrong, N. (ed.) (1974). Reconstructing social psychology. London: Penguin.

Bakan, D. (1967). Idolatory in religion and science. In D. Bakan (ed.) On method: Toward a reconstruction of psychological investigation (pp. 150-159). San Francisco, CA: Jossey-Bass.

Bakan, D. (1996). The crisis in psychology. Journal of Social Distress and the Homeless, 5, 335-342.

Bandura, A. (1977). Social learning theory. New York: General Learning Press.

Berger, M., \& Luckmann, T. (1966). The social construction of reality: a treatise in the sociology of knowledge. London: Penguin.

Brown, P. (1974). Toward a Marxist psychology. New York: Harper \& Row.

Bruner, J. (1990). Acts of meaning. Cambridge, MA: Harvard University Press.

Campbell, C., \& Murray, M. (2004). Community health psychology: definitions and challenges. Journal of Health Psychology, 9, 179-188.

Danziger, K. (1985). The methodological imperative in psychology. Philosophy of the Social Sciences, 15, 1-13.

Department of Health \& Social Security (1976). Prevention \& health - everybody's business. London: HMSO.

Department of Health \& Social Security (1980). Inequalities in health: Report of a research working group. London: HMSO. 
Dolby, S.K. (2005). Self-help books: why Americans keep buying them. Champagne, IL: University of Illinois Press.

Fairfield, S., Layton, L., \& Stack, C. (2002). Bringing the plague: Toward a postmodern psychoanalysis. New York: Other Press.

Farr, R.M. (1991). The long past and the short history of social psychology. European Journal of Social Psychology, 21, 371-380.

Fishbein, M., \& Ajzen, I. (1975). Belief, attitude, intention, and behavior: An introduction to theory and research. Reading, MA: Addison-Wesley

Fisk, R. (2011). How long before the dominoes fall? The Independent, 23 August.

Foucault, M. (1964). Madness and civilization: A history of insanity in the age of reason. London: Routledge.

Foucault, M. (1970). The order of things: An archaeology of the human sciences. London: Routledge.

Foucault, M. (1974). The birth of the clinic. London: Routledge.

Freidson, E. (1970). Profession of Medicine: A Study of the Sociology of Applied Knowledge, Chicago, IL: University of Chicago Press

Fukuyama, F. (1992). The end of history and the last man. New York: Penguin.

Harris, B. (2009). What critical psychologists should know about the history of psychology. In D. Fox, I. Prilleltensky \& . Austin (Eds.) Critical Psychology, An Introduction. Second edition (pp. 20-35). London: Sage.

Heather, N. (1976). Radical perspectives in psychology. London: Methuen.

Herzlich, C. (1973). Health and illness: a social psychological analysis. London: Academic.

Illich, I. (1974). Medical nemesis. London: Calder \& Boyars 
Israel, J., \& Tajfel, H. (Eds). (1972). The context of social psychology: a critical assessment. London: Academic.

Johnston, M., Weinman, J., Chater, A. (2011). A healthy contribution. The Psychologist, 24, 890-892.

Lubek, I. (1993). Some reflections on various social psychologies, their histories and historiographies. Sociétés Contemporaines, 13, 33-68.

Lynskey, D. (2011). 33 revolutions per minute: A history of protest songs, from Billie Holiday to Green Day. London: Ecco Books.

Lyons, A.C. (2011). Editorial: Advancing and extending qualitative research in health psychology. Health Psychology Review, 5(1), 1-8.

Martin-Baro, I. (1994). Writings for a liberation psychology: Ignacio Martin-Baro (A. Aron \& S. Corne, Eds.). Cambridge: MA: Harvard University Press.

Matarazzo, J.D. (1982). Behavioral health's challenge to academic, scientific and professional psychology. American Psychologist, 37, 1-14.

Moscovici, S. (1972). Society and theory in social psychology. In J. Israel \& H. Tajfel (Eds.) The context of social psychology: a critical assessment (pp. 17-68). London: Academic.

Murray, M. (1990). Lay representations of illness. In P. Bennett, J. Weinman \& P. Spurgeon (Eds.) Current developments in health psychology (p. 63-92). Chur: Harwood.

Murray, M. (Ed.) (2004). Critical health psychology. London: Palgrave.

Murray, M., \& Campbell, C. (2003). Beyond the sidelines: towards a more politically engaged health psychology. Health Psychology Update, 12, 9-20.

Murray, M., \& Chamberlain, K. Qualitative research in health psychology: developments and directions. Journal of Health Psychology, 3, 291-295. 
Murray, M., \& Chamberlain, K. (1999). Health psychology and qualitative research. In M. Murray \& K. Chamberlain (Eds.) Qualitative health psychology: Theories and methods (pp. 3-15). London: Sage.

Murray, M., \& Poland, B. (2006). Health psychology and social action. Journal of Health Psychology, 11, 379-384.

Murray, M., Nelson, G., Poland, B., Maticka-Tyndale, E., \& Ferris, L. (2004). Assumptions and values of community health psychology. Journal of Health Psychology, 9, 323-333

Ogden, J. (1997). The rhetoric and reality of psychosocial theories: a challenge to biomedicine. Journal of Health Psychology, 2, 21-29.

Ogden, J. (2003). Some problems with social cognition models: a pragmatic and conceptual analysis. Health Psychology, 22, 424-428.

Parker, I. (1989). The crisis in modern social psychology - and how to end it. London: Routledge.

Potter, J., \& Wetherell, M. (1987). Discourse and social psychology: Beyond attitudes and behavior. London: Sage.

Rose, N. (1996). Inventing ourselves: Psychology, power and personhood. Cambridge: Cambridge University Press.

Rose, N. (1985). The Psychological Complex. London: Routledge.

Rose, N. (2007). Psychology as a social science. Unpublished lecture given at London School of Economics, February 2007.

Ryan, W (1976). Blaming the victim, Second edition. New York: Vintage.

Sarbin, T.R. (1986). Narrative psychology: The storied nature of human conduct. New York: Praeger.

Shotter, J. (1975). Images of man in psychological research. London: Methuen 
Smith, J.A. (2011). Evaluating the contribution of interpretative phenomenological analysis. Health Psychology Review, 5(1), 9-27.

Smith, R. (1997). The Fontana history of the human sciences. London: Fontana.

Stam, H.J. (2004). A sound mind in a sound body: a critical historical analysis of health psychology. In M. Murray (Ed.) Critical health psychology. Basingstoke: Palgrave.

Stephens, C. (2011). Narrative analysis in health psychology research: personal, dialogical and social stories of health. Health Psychology Review, 5(1), 62-78.

Stone, G.C. (1991). An international review of the emergence and development of health psychology. In M.A. Jansen \& J. Weinman (Eds.) The international development of health psychology. Chur: Hawood.

Stringer, P. (1990). Prefacing social psychology: A textbook example. In I. Parker \& J. Shotter (Eds.) Deconstructing social psychology. London: Routledge.

Szasz, T. (1961). The myth of mental illness: Foundations of a theory of personal conduct. New York: Harper \& Row.

Teo, T. (2005). The critique of psychology. New York: Springer.

Toulmin, S., \& Leary, D.E. (1985). The cult of empiricism in psychology and beyond. In S. Koch \& D.E. Leary (Eds.) A century of psychology as science (pp. 594-617). New York: McGraw-Hill.

Wallston, K.A. (1997). A history of Division 38 (Health psychology): Healthy, wealthy, and Weiss. In D.A. Dewsbury (Ed.) Unification through division: Histories of the Divisions of the American Psychological Association, Volume II. Washington, DC: APA Books.

Wexler, P. (1983). Critical social psychology. Boston: Routledge \& Kegan Paul.

Willig, C. (2012). Qualitative interpretation and analysis in psychology. Maidenhead: Open University Press. 
Wolfe, T. (1976). The 'me' decade and the third great awakening. New York, 23 August, 2640.

' Quoted in 'There is no place for kids now: Ken Loach talks to Kira Cochrane'. The Guardian, G", 29 August, p. 7-9. 